\title{
INCREASE OF SHELF OF DECOCTION BY PASTEURIZATION AND STERILIZATION (TRIPALA QUATHA)
}

\author{
by
}

W. Sunethra Keriyawasam

M.Sc. 


\title{
INCREASE OF SHELF OF DECOCTION BY PASTEURIZATION AND STERILIZATION (TRIPALA QUATHA)
}

\author{
by \\ W. Sunethra Keriyawasam
}

Thesis submitted to the University of Sri Jayewardenepura for the award of degree of Master Science in food Science \& Technilogy in 2006 


\section{Declaration}

The work described in this was carried out by me under the supervision of prof: A. Bamunuarachchi and Dr. K.K.D.S. Ranaweera and a report on this has not been submitted in whole or in part to any other institution for another Degree / Diploma

W.S. Kanifawalam

W. Sunethra Keriyawasam 
We certify that the above statement made by the candidate is true and that this thesis is suitable for submission to the University for the purpose of evaluation.
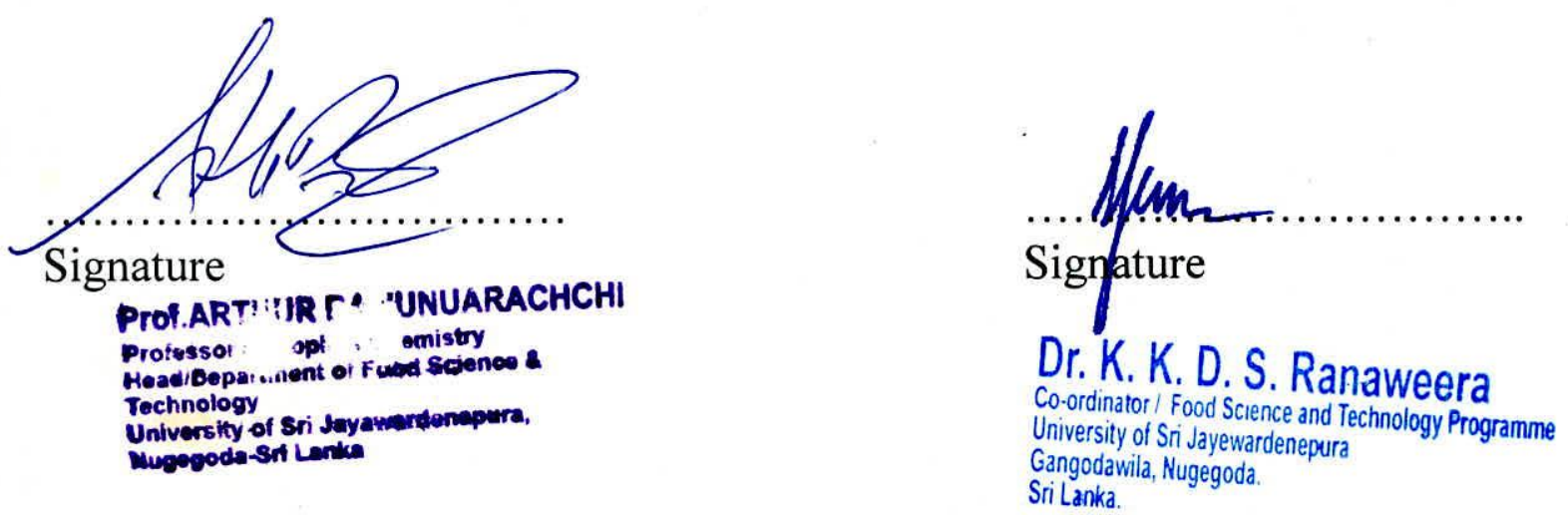


\section{$\underline{\text { Abstract }}$}

Almost all ayurvedic drugs are of herbal nature and make significant contribution in many fields including food technology. After harvesting, raw materials may undergo spoilage due to metabolic changes, mechanical injuries pest attacks etc. Spoilage can also be resulted soon after the processing or due to exposure of products to the environment.

Similarly decoctions can be spoiled after 2-3 days from the preparation date becoming sour in taste. These preparations can be of different quality and may be harmful for patients.

Therefore, finding a method or a technique which can be used to extend the shelf life of these products is of primary significance. A study was carried out to investigate factors affecting the spoilage of thripala, one of the most popular decoctions prescribed for many health complications. In this study, a special emphasis was given to shape of containers, cleanliness of raw materials and different heat treatments in order to minimize the spoilage.

Hence, the decoction was prepared in good hygienic conditions and was hot filled into glass bottles which were subsequently sterilized by steam.

The drug can be preserved for one-month period when the bottles were filled by hot filling method. The decoction is heated to $95{ }^{\circ} \mathrm{C}$ and filled into the sterilized narrow mouthed bottles keeping the temperature at $95{ }^{\circ} \mathrm{C}$ and sealed. Under proper sanitary storage conditions these bottles can be stored for more than two weeks. These sealed bottles subjected to steaming have extended the shelf life for one month. 


\section{Acknowledgement}

I am mostly grateful to my supervisor Arthur Bamunuarachchi and Dr. K.K.D.S. Ranaweera of the Department of Food Science and Technology, University of Sri Jayawardanepura for his invaluable supervision, guidance and encouragement throughout this project. I also wish to express my sincere thanks to Dr. K.K.D.S. Ranaweera, the head of the Department of Food Science and Technology, University of Sri Jayawardenapura for his interest and valuable assistance in the chemical and microbiological analysis through out this research project.

My gratitude also goes to Mrs. Rupika perera Research Officer, and Mrs. Indira Wickramasinghe of the Department of Food Science and Technology University of Sri Jayawardanapura for the valuable technical guidance given to me throughout this project.

I would also like to thank Mr. Sisira Weerasinghe; Technical Officer of the Department of food Science and Technology, University of Sri Jayawardanapura for the valuable Technical assistance.

I remember my colleagues and all non academic staff members of the Department of Food Science and Technology, with gratitude for their immeasurable assistance to carry out this project successfully.

Finally my remembrance goes to my husband, Lalantha and my Son for continued support and encouragement during this venture 


\section{Table of Content}

Abstract

Acknowledgement

Table of Content

List of Figures

List of Tables

CHAPTER - 01

Introduction

CHAPTER - 02

Literature Review

2.1 Phyllanthus emblica 3

$\begin{array}{lll}\text { 2.1.1 Classical Names } & 3\end{array}$

2.1.1.1 Vernacular Names 5

2.1.2 Botanical Description 5

2.1.3 Distribution 5

2.1.4 Parts Used 5

2.1.5 Action And Uses 5

2.1.6 Ayurvedic Properties 6

2.1.7 Pharmacognosy 7

$\begin{array}{lll}2.1 .8 & \text { Fresh Fruits } & 7\end{array}$

$\begin{array}{lrr}\text { 2.1.9 } & \text { Dried mature fruit } & 8\end{array}$

$\begin{array}{lr}\text { 2.1.10 Physical Constants } & 8\end{array}$

2.1.11 Chemical Constituents 9

2.1.12 Pharmacological Activities 9

2.1.13 Toxicology 9

$\begin{array}{ll}2.2 \text { Terminalia bellirica } & 9\end{array}$

2.2.1 Classical Names 9

2.2.1.1 Vernacular Names 11

2.2.2 Botanical Discription 11

$\begin{array}{lll}2.2 .3 & \text { Distribution } & 11\end{array}$ 
2.2.6 Ayurvedic properties 12

2.2.7 Pharmacognosy 12

$\begin{array}{llr}\text { 2.2.8 Physical constants } & 13\end{array}$

$\begin{array}{ll}\text { 2.2.9 Chemical Constituents } & 13\end{array}$

2.2.10 Pharmacological Activities $\quad 13$

$\begin{array}{lll}\text { 2.2.11 Toxicology } & 13\end{array}$

$\begin{array}{lll}\text { 2.2.12 Substitutes And Adulterants } & 13\end{array}$

$\begin{array}{llr}2.3 & \text { Terminalia Chebula } & 14\end{array}$

$\begin{array}{ll}\text { 2.3.1 Classical Names } & 14\end{array}$

2.3.1.1 Vernacular Names 14

2.3.2 Botanical Description 14

$\begin{array}{lll}2.3 .3 & \text { Distribution } & 14\end{array}$

$\begin{array}{lll}2.3 .4 & \text { Parts Used } & 14\end{array}$

$\begin{array}{lll}\text { 2.3.5 Action And Uses } & 16\end{array}$

$\begin{array}{ll}\text { 2.3.6 Ayurvedic properties } & 16\end{array}$

$\begin{array}{ll}\text { 2.3.7 Pharmacognocy } & 17\end{array}$

$\begin{array}{lll}\text { 2.3.8 Physical constants } & 17\end{array}$

$\begin{array}{lll}\text { 2.3.9 Chemical Constituents } & 18\end{array}$

$\begin{array}{ll}\text { 2.3.10 Pharmacological Activities } & 18\end{array}$

$\begin{array}{lll}2.3 .11 & \text { Toxicology } & 18\end{array}$

$\begin{array}{ll}\text { 2.3.12 Substitutes And Adulterants } & 18\end{array}$

2.4. Traditional Decoction 19

Heat Treatment 19

2.5 Thermal Processing of Liquid Foods 19

2.5.1. . Pasteurization 19

2.5.2. Pasteurization by Retort 20

2.5.3. Moist Heat Steam under Pressure Autoclave 21

2.5.4 Dry Heat Hot air Sterilization 23 
2.5.5 Requirement Of Quality Control Of Drug 23

2.5.6 Quality Standards And Grades 24

2.6.1. Cleaning and washing 24

2.6.2. Containers 25

2.6.3. Storage 25

2.6.4. Labeling 26

$\begin{array}{ll}\text { CHAPTER - } 03 & 27\end{array}$

Experiment \& Methodology

Methodology

$\begin{array}{llr}3.1 & \text { Method } & 27\end{array}$

3.2. Preparation of decoction (Quatha) 28

$\begin{array}{ll}\text { 3.2.1. Equipments } & 28\end{array}$

3.2.2. Method 28

3.2.2.1 Sorting- 29

3.2.2.2 Storage Process 29

3.2.2.3 Cleaning and Washing- 29

3.2.2.4 Crushing - 29

3.2.2.5 Weighing - 29

3.2.2.6. Method of Preparation of decoction - 30

$\begin{array}{ll}\text { 3.2.2.7. Filtration } & \mathbf{3 0}\end{array}$

$\begin{array}{ll}\text { 3.2.2.8. Pasteurization } \& \text { sterilization } & 30\end{array}$

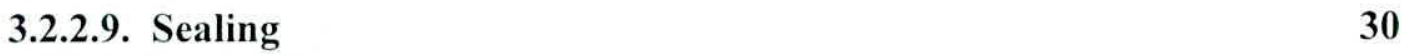

3.2.2.10. Steaming 31

$\begin{array}{llll}\text { 3.2.2.11. Labeling \& Storaging } & 31\end{array}$ 


\section{Experiment}

3.3 Physico Chemical and biological analysis of

Raw material

3.3.1 Preparation of sample for analysis 32

3.3.2. Determination of loss on drying (at $\left.105{ }^{\circ} \mathrm{C}\right) \quad 32$

3.3.3. Determination of total Ash 32

3.3.4. Determination of Water insoluble Ash 33

3.3.5. Determination of Water soluble Ash 33

3.3.6. Determination of Acid insoluble Ash 34

3.3.7. Determination of alcohol soluble extractive 34

3.3.8. Determination of water soluble extractive 35

3.3.9. Determination of Petroleum ether soluble extractive 35

3.3.10. Determination of Chloroform soluble extractive 36

3.3.11. Determination of Volatile oil content 36

3.4. Experiment I -: Determine the bitter compounds in 37 Raw materials (Aralu, Bulu, Nelli)

3.4.1 Materials 37

$\begin{array}{ll}\text { 3.4.2 Method } & 37\end{array}$

3.5 Experiment II -: Determination of Alkaloid compounds 38 in Raw material (Aralu, Bulu, Nelli)

3.5.1 Method 38

3.6. Physico Chemical and biological analysis of Product 39

3.6.1. Determination of moisture content experimental 39

3.6.2. Determination of total ash 40

3.6.3. Determination of $\mathrm{PH}$ value of decoction 41

3.6.3.1. Principle 41

$\begin{array}{lll}\text { 3.6.3.2. Materials } & 41\end{array}$ 
3.6.4. Determination of sugar contant. 41

3.6.4.1 Method for the determination of total sugar content 42

3.6.4.2 Method for the determination of Reducing sugar content 43

3.6.5. Determination of soluble solids contents. 43

3.6.6 Determination of Specific gravity 44

3.6.7 Determination of refractive index 44

3.6.8. Determination of Alcohol content 44

3.7. Determination of microbial growth. 45

3.7.1 Experiment I (Step I) 45

3.7.2 Microbiology media Preparation 45

$\begin{array}{llll}\text { 3.7.3 Experiment I (Step II) } & 47\end{array}$

$\begin{array}{ll}3.7 .4 \text { Incubation } & 49\end{array}$

Experiment I (Step III) $\quad \mathbf{5 0}$

3.7.5. Gram Stain $\quad \mathbf{5 0}$

3.7.6 Experiment II

3.7.7 Experiment III

3.8. Storage Condition 52

CHAPTER 4

Results \& Discussion

4.1 Plant facilities and processing requirements. 54

4.2 Sanitary facilities \& control $\mathbf{5 5}$

4.2.1 Control separations $\quad 55$

4.2.2 Sanitary facilities $\quad 55$

4.3 Preparation \& processing $\quad 55$

4.4 Chemical Analysis of Raw Materials 56

4.5 Determine the bitter compounds in Raw materials 57 Aralu, Bulu, Nelli

4.6 Determination of Alkaloid compounds in Raw material 58 (Aralu, Bulu, Nelli) 
4.7 Oven Drying Method $\quad 59$

$\begin{array}{lll}4.8 \text { Ash content of Thripala Quatha } & 60\end{array}$

4.9 Ash Content $\quad 60$

$4.10 \mathrm{pH}$ value of Decoction $\quad 61$

$\begin{array}{ll}4.11 \text { Total sugar content } & 61\end{array}$

4.12. Reducing Sugar 62

4.13 Soluble Solids Contents $\quad 62$

4.14 Specific gravity $\quad 63$

4.15 Refractive index $\quad 63$

4.16 Alcohol content $\quad 64$

4.17 Determination of Microbial growth $\quad 64$

4.17.1. Experiment I (Step I)

4.17.2. Experiment I (Step II)

4.17.3. Experiment I (Step III) 66

$\begin{array}{ll}\text { 4.17.3.1. Experiment I (Step III) } & 67\end{array}$

4. 18. Experimental II 67

4. 19. Experimental III $\quad 68$

4.20. Storage candition

$\begin{array}{ll}\text { Conclusion } & 74\end{array}$

References 
FIG - 01- Raw materials (Aralu, Bulu, Nelli)

FIG - 02- Amalaki - Phyllanthus embelica Linn. (Nelli) $\quad 04$

FIG - 03- Terminalia bellirica $\quad 10$

FIG- 04- Terminalia chebula (Aralu)

FIG - 05- Autoclave $\quad 22$

FIG - 06- Auto clave 31

FIG - 07- Determine the bitter compounds in Raw materials 37

FIG - 08- Determine of Alkaloid compounds in Raw material 38

FIG - 09- Colonies and mould could be seen after 24-48 hour 48

FIG - 10- Incubation $\quad 49$

FIG - 11- Storage Condition

FIG-12 \& 13-bitter compounds in Raw materials 57

FIG-14\& 15-Alkaloid compounds in Raw material 58

FIG - 16- Microbiology media Preparation $\quad 64$

FIG - $17 \&$ 18-Colonies and mould could be seen after 24-48 hours $\quad 65$

FIG - 19- Gram Stain $\quad 66$

FIG - 20- Cell, which separated from FIG 19

FIG - 21- Agar Plates $\quad 68$

FIG - 22- $750 \mathrm{ml}$ bottle at $45^{\circ} \mathrm{C} \quad 70$

FIG - 23-Mould and growth.

FIG - 24- 200ml Bottle $\quad 71$

FIG - $25 \& 26$ - View of mould and growth. 72

FIG - $27 \& 28-200 \mathrm{ml} \& 250 \mathrm{ml}$ Bottle 
Table - 2.1- Temperature of steam under pressure 21

Table-3.1- Macconkey Broth test 51

Table - 4.1-Chemical Analysis of Raw Materials 56

Table-4.2- Oven Drying Method 59

Table - 4.3 - Ash content of Thripala Quatha 60

Table-4.4- Ph value of Decoction 61

Table-4.5-Soluble Solids Contents 62

Table - 4.6-Specific gravity 63

Table - 4.7- Refractive index 63 


\section{CHAPTER - 01}

\section{Introduction}

Sri Lanka is one of the developing countries which has poorly developed pharmaceutical manufacture in both Ayurvedic and allopathic system of medicine. Therefore the country requirement is mainly met by the neighboring countries and for this purpose Sri Lanka's foreign exchange is lost considerably. This can be reduced if the drug manufactures. Duty specially the traditional drug manufacturer rule tends and applies appropriately devoted modern process technology.

Ayurveda is one of the oldest systems of the world. Ayurvedic physicians preferably like to dispense drugs prepared by their own hands. They do not rely upon the products manufactured by pharmaceutical industries. Rapid civilization, explosive growth rate of population, massive deforestation has made the physicians handicap and to depend upon pharmaceutical industries. Due to commercial orientation and increasing demand of natural products few pharmacies are preparing unethical products which result an embarrassing position for physicians and patients. In order to overcome these problems there is a need to implement certain standards for these natural products, which are easily adaptable and implementable to overcome the crisis.

The process of manufacturing medicines from raw ingredients to finished products requires a degree of control that is probably unequalled in any other industry. The role of the microbiological specification is to provide a standard for pharmaceutical preparation to ensure its safety for use. The microbiological controls for non-sterile and sterile product are different. The microbiological control has the same importance as the physical and chemical quality control. To gain a proper understanding of the source of microbial contamination, it is necessary to control microbes various stages of manufacturing and for each stage. To identify 